University of Nebraska - Lincoln

DigitalCommons@University of Nebraska - Lincoln

$1-2009$

\title{
Role of Invasive Melilotus officinalis in Two Native Plant Communities
}

Laura C. Van Riper

University of Minnesota, St. Paul

Diane Larson

USGS Northern Prairie Wildlife Research Center, dlarson@usgs.gov

Follow this and additional works at: https://digitalcommons.unl.edu/usgsnpwrc

Part of the Other International and Area Studies Commons

Van Riper, Laura C. and Larson, Diane, "Role of Invasive Melilotus officinalis in Two Native Plant Communities" (2009). USGS Northern Prairie Wildlife Research Center. 77.

https://digitalcommons.unl.edu/usgsnpwrc/77

This Article is brought to you for free and open access by the US Geological Survey at DigitalCommons@University of Nebraska - Lincoln. It has been accepted for inclusion in USGS Northern Prairie Wildlife Research Center by an authorized administrator of DigitalCommons@University of Nebraska - Lincoln. 


\title{
Role of invasive Melilotus officinalis in two native plant communities
}

\author{
Laura C. Van Riper • Diane L. Larson
}

Received: 29 January 2008/ Accepted: 21 May 2008/Published online: 8 June 2008

(C) Springer Science+Business Media B.V. 2008 This article is a U.S. government work, and is not subject to copyright in the United States.

\begin{abstract}
This study examines the impact of the exotic nitrogen-fixing legume Melilotus officinalis (L.) Lam. on native and exotic species cover in two Great Plains ecosystems in Badlands National Park, South Dakota. Melilotus is still widely planted and its effects on native ecosystems are not well studied. Melilotus could have direct effects on native plants, such as through competition or facilitation. Alternatively, Melilotus may have indirect effects on natives, e.g., by favoring exotic species which in turn have a negative effect on native species. This study examined these interactions across a 4-year period in two contrasting vegetation types: Badlands sparse vegetation and western wheatgrass (Pascopyrum smithii) mixed-grass prairie. Structural equation models were used to analyze the pathways through which Melilotus,
\end{abstract}

L. C. Van Riper

Department of Ecology, Evolution, and Behavior, University of Minnesota, 1987 Upper Buford Circle, St. Paul, MN 55108, USA

Present Address:

L. C. Van Riper

Department of Agronomy and Plant Genetics, University of Minnesota, 411 Borlaug Hall, 1991 Upper Buford Circle, St. Paul, MN 55108, USA

D. L. Larson $(\bowtie)$

U.S. Geological Survery, Northern Prairie Wildlife Research Center, 100 Ecology Building, 1987 Upper Buford Circle, St. Paul, MN 55108, USA

e-mail: dlarson@usgs.gov native species, and other exotic species interact over a series of 2-year time steps. Melilotus can affect native and exotic species both in the current year and in the years after its death (a lag effect). A lag effect is possible because the death of a Melilotus plant can leave an open, potentially nitrogen-enriched site on the landscape. The results showed that the relationship between Melilotus and native and exotic species varied depending on the habitat and the year. In Badlands sparse vegetation, there was a consistent, strong, and positive relationship between Melilotus cover and native and exotic species cover suggesting that Melilotus is acting as a nurse plant and facilitating the growth of other species. In contrast, in western wheatgrass prairie, Melilotus was acting as a weak competitor and had no consistent effect on other species. In both habitats, there was little evidence for a direct lag effect of Melilotus on other species. Together, these results suggest both facilitative and competitive roles for Melilotus, depending on the vegetation type it invades.

Keywords Badlands sparse vegetation .

Exotic legumes - Invasive plants ·

Nitrogen fixer - South Dakota .

Structural equation models - Mixed-grass prairie

\section{Introduction}

When exotic nitrogen-fixing plants become abundant in natural areas, they have been shown to increase 
nitrogen $(\mathrm{N})$ levels and accelerate the rate of $\mathrm{N}$ cycling (Haubensak and Parker 2004; Vitousek and Walker 1989; Vitousek et al. 1987; Wheeler et al. 1987). Nitrogen is a limiting resource in many ecosystems, and the changes in competitive dynamics between plant species due to increased $\mathrm{N}$ can potentially cause broad changes in the composition of native communities (Vitousek and Walker 1989). Native species often are better adapted to lower $\mathrm{N}$ levels present in the unaltered ecosystem (Arendt 1997; Hobbie 1992; McLendon and Redente 1992). In contrast, many invasive exotic species are well adapted to exploiting high $\mathrm{N}$ sites and have high dispersal rates that allow rapid colonization (Cousens and Mortimer 1995; Maron and Connors 1996; Rejmanek and Richardson 1996). Once at a N-rich site, exotic species can exploit $\mathrm{N}$ more quickly than later successional natives by increasing growth rates in response to higher nutrient availability (Carson and Barrett 1988; Fogarty and Facelli 1999). Nitrogen enrichment by exotic $\mathrm{N}$-fixing species can facilitate the further invasion by other exotic species (Adler et al. 1998; Carino and Daehler 2002; Maron and Jefferies 1999; Sher and Hyatt 1999), moving the system toward an "invasional meltdown" (Simberloff 2006; Simberloff and Von Holle 1999).

Melilotus officinalis (L.) Lam. (hereafter Melilotus) is a biennial legume (Fabaceae) native to Eurasia that has become naturalized throughout the world (Klebesadel 2001; Turkington et al. 1978; Wu et al. 2003) and has been recognized as a conservation problem in natural areas in North America (Lesica and DeLuca 2000; Turkington et al. 1978; Weaver et al. 2001; Wolf et al. 2003). The effects of Melilotus on native species and ecosystems in the North American Great Plains are largely unknown. Melilotus may cause ecosystem-level changes due to its association with Sinorhizobium meliloti bacteria, which allows it to fix atmospheric $\mathrm{N}$ and thus potentially enrich the soil (Turkington et al. 1978; Wivstad 1999; Zakhia and de Lajudie 2001). Great Plains habitats invaded by Melilotus are historically low-N systems (Clark et al. 1980; Woodmansee 1978). Competition with living Melilotus may decrease the cover of both native and exotic species (Wolf et al. 2003), but if N-rich patches remain after the death of Melilotus, exotics could be favored over natives (Carino and Daehler 2002; Maron and Jeffries 2001).
Native species diversity also can decline through interactions with Melilotus. Increased $\mathrm{N}$ often reduces evenness, resulting in the replacement of a diverse community by one or a few dominant species (Carson and Barrett 1988; Tilman 1987; Willems et al. 1993). Monoculture-forming exotic species also may outcompete native species (Mack et al. 2000; Mooney and Drake 1986; Wilcove et al. 1998). Melilotus's effects on native species diversity may therefore be direct, via competition (e.g., space, water, nutrients, or light), and/or indirect via alteration of the $\mathrm{N}$ cycle.

Melilotus is still widely planted, despite uncertainties in its effect on native species and ecosystems (Lesica and DeLuca 2000; Turkington et al. 1978; Weaver et al. 2001). The purpose of this study is to evaluate the effects of Melilotus on native and exotic species cover; the interactions between Melilotus, native, and other exotic species; and the variations in those interactions from year-to-year. Specifically, we use structural equation modeling (Grace 2006) to address the following questions: (1) Is there an association between live Melilotus cover and the cover of native and other exotic species? (2) Can we detect a lag in the association between Melilotus cover and cover of native and other exotic species (i.e., has Melilotus left some legacy in the soil after its death)? (3) Do other exotic species present in our study influence native cover in the current year or as a lag effect? (4) Can we detect an association in cover between consecutive years within each group (Melilotus, native species, and other exotic species)? (5) Can we detect an effect of native and exotic species cover on Melilotus cover?

\section{Methods}

Study site

Badlands National Park is located in the northern Great Plains in southwestern South Dakota, USA. The region has a semiarid climate with short, hot summers $\left(22^{\circ} \mathrm{C}\right.$ average $)$ and cold winters $\left(-4^{\circ} \mathrm{C}\right.$ average) (Nielsen 1996). The average total precipitation is $39.5 \mathrm{~cm}$, of which $75 \%$ falls between April and September (Nielsen 1996). During the years of our study, precipitation varied $>1$ standard deviation above and below the 30 -year mean (Fig. 1). The park is dominated by two ecosystems, western 


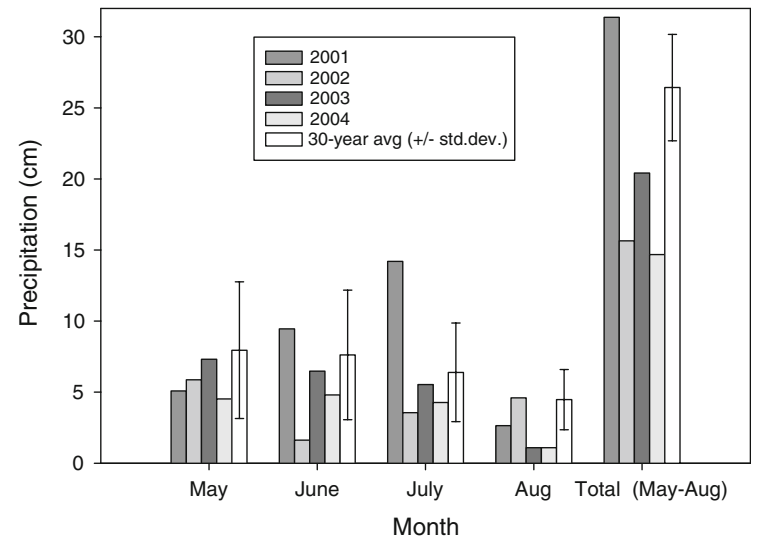

Fig. 1 Precipitation at Badlands National Park in southwestern South Dakota during the 2001-2004 growing seasons. The 30 -year average ( \pm standard deviation) also is included. Precipitation data are from the National Oceanic and Atmospheric Administration (NOAA) weather station in Interior, SD

wheatgrass-green needlegrass (Pascopyrum smithii (Rydb.) A. Löve-Nassella viridula (Trin.) Barkworth) mixed-grass prairie (hereafter, wheatgrass prairie) and Badlands sparse vegetation (hereafter, sparse vegetation). Wheatgrass prairie covers $36.6 \%$ of the park and has plant cover levels of $45-100 \%$ (Von Loh et al. 1999). Sparse vegetation covers $45.5 \%$ of the park, occurs in areas with highly erodible soils, and has plant cover levels of 5-10\%.

Wheatgrass prairie and sparse vegetation differ in their dominant species. Common species in wheatgrass prairie include perennial native grasses such as western wheatgrass, green needlegrass, blue grama (Bouteloua gracilis (Willd. ex Kunth) Lag. ex Griffiths, Poaceae), and buffalograss (Buchloe dactyloides Nutt. Englem., Poaceae), the annual exotic grass Japanese brome (Bromus japonicus Thunb. ex Murr., Poaceae), and the perennial native forb scarlet globemallow (Sphaeralcea coccinea (Nutt.) Rydb., Malvaceae). Common species in sparse vegetation include perennial native forbs such as broom snakeweed (Gutierrezia sarothrae (Pursh) Britt. \& Rusby, Asteraceae) and fewflower buckwheat (Eriogonum pauciflorum Pursh, Polygonaceae), the native shrub fourwing saltbush (Atriplex canescens (Pursh) Nutt., Chenopodiaceae), the biennial native forb curlycup gumweed (Grindelia squarrosa (Pursh) Dunal, Asteraceae), and the annual exotic forb Russian thistle (Salsola tragus L., Chenopodiaceae). Taxonomy follows USDA Plants (www.plants.usda.gov; accessed 1/2/08).
Soils and associated ecosystem properties also differ between wheatgrass prairie and sparse ecosystems (all soil information from U.S. Department of Agriculture soil surveys: Nielsen 1996; Schlepp 1987). The mollisols on which wheatgrass prairie species grow are characterized as deep, well drained, and nearly level with low organic content and slow water runoff. The soils are generally calcareous loams and some are sodium rich. At Badlands National Park, the soils on which the sparse vegetation grows are aridisols and entisols. The soils can be very shallow and often are composed of mudstone, siltstone, and shale. These soils vary from calcareous clay loams to calcareous clays and have low organic matter content, low fertility, low water capacity, and very slow permeability. The Badlands areas where most sparse vegetation is located are steep with many drainage channels and have high runoff potential and active erosion.

Vegetation sampling

Vegetation sampling occurred during May, June and July on permanent plots in the two ecosystems. Random points within each vegetation type were generated using ArcView (ESRI 2001) and up to three permanent plots were established at each randomly located point. The number of plots sampled varied from year-to-year due to differences in field crew availability. There were up to 50 random points in each vegetation type and a maximum of 107 plots in wheatgrass prairie and 119 plots in sparse vegetation. At each random point, one permanently marked $2 \mathrm{~m} \times 6 \mathrm{~m}$ plot was located at the random point and up to two permanently marked $2 \mathrm{~m} \times 6-\mathrm{m}$ plots were located near the random point (within $100 \mathrm{~m}$ ). The nearby plots were chosen to represent the range of Melilotus cover at the site (from low to high percent cover of Melilotus). To quantify the plant community within a plot, all plant species and their Daubenmire (1959) cover classes were recorded in each of 12 $0.5 \mathrm{~m} \times 2-\mathrm{m}$ segments (this covers the entire plot). The cover classes for the 12 segments were averaged, resulting in a cover class for each species for the plot and a total species list. Native and exotic species cover class midpoints were summed for total cover of native and exotic species per plot. The number of native and exotic species was summed to give native and exotic species richness per plot. The exotic species category refers to all exotic species present except Melilotus. 
Data from the random plots provide general trends for the study site over the course of the study. Native versus exotic status of the plant species follow the Great Plains Flora Association (1986).

\section{Statistical analysis}

The percent cover data are reported as proportional data. Mean cover and richness values for each vegetation type in each year were determined. Although we report species richness as part of our site characterization, we do not statistically analyze these data due to space limitations. Model results were similar for species richness and cover (Van Riper 2005).

We used structural equation models (Chapter 30, McCune and Grace 2002) to analyze the multivariate relationships in the plant cover data (Fig. 2, explained below). Proportional data were arcsine square root transformed to increase normality and reduce kurtosis. We structured the data into time steps (2001-2002 and 2002-2003 for wheatgrass prairie and 2001-2002, 2002-2003, and 2003-2004 for sparse vegetation) so that each time step was a group, and used multi-group analysis in Amos v. 7 (Arbuckle 2006) to ask (1) if the same model fit the data for each time step; and (2) if path (standardized regression) coefficients were the same for all time steps, given that the same model fit each time step. For a discussion of multigroup analysis using structural equation models, see Grace (2006). Because data were collected prior to model formulation, the models presented are considered exploratory rather than "strictly confirmatory" (Jöreskog and Sörbom 1996).

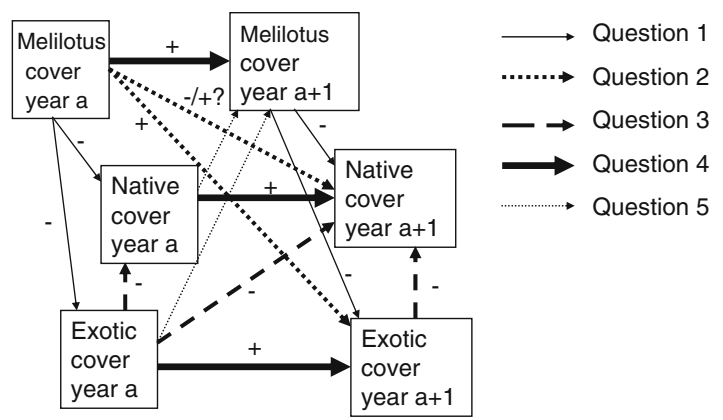

Fig. 2 The hypothesized model. The sign (+ or - ) indicates the hypothesized relationship (positive or negative) of the variable at the origin of the arrow to the variable at the point of the arrow. The different line formats of the arrows refer to the different questions posed in our study (see "Introduction" section)
The model (Fig. 2) was used to examine the relationship between Melilotus cover and native and exotic species cover. In the model, single-headed (unidirectional) arrows represent causal pathways (Hatcher 1994). The output of Amos provides a $\chi^{2}$ significance test for the null hypothesis that the data fit the model. If $P<0.05$ the null hypothesis is rejected, indicating that the data are inconsistent with the model (Hatcher 1994). The significance of the coefficient of each path also is determined. Paths with $P>0.05(t<1.96)$ are considered to have coefficients that are not different from zero. For paths with significant coefficients, the standardized path coefficients, which indicate the strength of the relationship between the variables, are reported. For example, if the path from Variable 1 to Variable 2 has a standardized path coefficient of 0.50 , then there is an increase of 0.50 standard deviations in Variable 2 for an increase of 1 standard deviation in Variable 1, while holding constant the effects of other variables (Hatcher 1994). The $R^{2}$ values, showing the total explained variance, are presented for the dependent variables (Mitchell 1993).

Our goal was to assess the influence of Melilotus in each vegetation type. We hypothesized that Melilotus cover was influencing the covers of native species and other exotic species. The sign and significance of path coefficients between Melilotus and native and exotic species covers, as determined by structural equation models, can support or counter our hypothesis. The focal questions, corresponding to the arrows in the model (Fig. 2), are:

1. Does Melilotus in year $a$ inhibit natives and other exotics in year $a$ and/or does Melilotus in year $a+1$ inhibits natives and other exotics in year $a+1$ ?

2. Is there a lag effect of Melilotus? This examines the effect of Melilotus in year $a$ on natives and other exotics in year $a+1$.

3. Does the cover of other exotic species in year $a$ inhibit natives in year $a$ or $a+1$, and/or does the cover of other exotic species in year $a+1$ inhibit natives in year $a+1$ ?

4. Does the cover of Melilotus, natives or other exotics in year $a$ influence their cover in year $a+1$ ? Measurements were made on permanent plots, so we expect that Melilotus, other exotic, and native cover in year $a+1$ will be strongly 
related to Melilotus, other exotic, and native cover, respectively, in year $a$.

5. Does the cover of native and other exotic species in year $a$ influence Melilotus cover in year $a+1$ ? We anticipate that Melilotus is not strongly inhibited by native or exotic species cover as Melilotus populations can invade a variety of habitats.

Observational data from two vegetation types at Badlands National Park were used to address the study questions. Because the two vegetation types, wheatgrass prairie and sparse vegetation, differ dramatically in the processes that shape them, the relationship between each vegetation type and Melilotus could also differ. In wheatgrass prairie, we hypothesized that live Melilotus cover would inhibit growth of natives and other exotics in year $a$ due to competition, but the $\mathrm{N}$ rich patches left behind the next year (i.e., year $a+1$ ) would disproportionately favor exotic species over natives. (Because not all Melilotus plants measured in year $a$ will die by year $a+1$, this effect is predicted to be relatively weak.) Native species would be disfavored if exotics can better exploit the increased $\mathrm{N}$. There is potential for year-to-year variation in the strength of these effects due to environmental factors, such as varying amounts of precipitation. Melilotus itself can vary widely in population abundance from year-to-year, with large Melilotus populations found in years of high precipitation (Von Loh et al. 1999).

The same model applies for sparse vegetation, but it is less clear what effect Melilotus would have in year $a$. In this harsher, less vegetated environment, Melilotus may act as a nurse plant in year $a$ for both native and exotic plants (O'Connor 1995; Walker and Vitousek 1991), unlike the competitive relationship hypothesized for the more densely vegetated wheatgrass prairie habitat.

\section{Results}

Site characterization

Throughout Badlands National Park, Melilotus presence in our plots varied substantially among years and vegetation types, ranging from $29 \%$ of individual plots occupied in sparse vegetation in 2004 to $>80 \%$ of individual plots occupied in wheatgrass prairie in 2001; Melilotus always occurred more frequently in wheatgrass prairie than in sparse vegetation (Table 1). Although frequency of occurrence was generally high, Melilotus cover averaged only $2-8 \%$ in wheatgrass prairie and $1-3 \%$ in sparse vegetation (Table 1). In all plots (not only those at the random points), Melilotus cover ranged from 0 to $50-75 \%$ cover in wheatgrass prairie and from 0 to $25-50 \%$ cover in sparse vegetation. While other exotic species were common in both habitats, native species cover and richness exceeded other exotic species cover and richness. Native and other exotic species richness was higher in wheatgrass prairie plots than sparse vegetation plots (Table 1). In total, 22 exotic species were found in wheatgrass prairie plots and nine exotic species were found in sparse vegetation plots (species are listed in Van Riper 2005).

\section{Model evaluation}

We used our hypothesized model (Fig. 2) to examine the effect of Melilotus cover on native and exotic species cover in wheatgrass prairie and sparse vegetation. The models for wheatgrass prairie (Fig. 3) and sparse vegetation (Fig. 4) were examined to determine the answers to the initial questions (summarized in Table 2).

Q1 Does Melilotus cover in year $a$ inhibit native and other exotic species cover in year $a$ ?

Model results for wheatgrass prairie were inconsistent both within and between 2-year time steps (Table 2). For example, although Melilotus cover had a fairly strong negative association with native cover in 2001, there were no significant associations in the other years (Fig. 3). Only in 2003 did we find any association of Melilotus cover with exotic species cover, and it was negative (Table 2, Fig. 3). In contrast, we found consistent positive associations of Melilotus cover with both native and exotic species in sparse vegetation (Table 2, Fig. 4).

Q2 Does Melilotus cover in year a promote other exotic cover and reduce native cover in year $a+1$ ? (Does Melilotus have a lag effect?)

There was slight evidence for a lag effect in wheatgrass prairie, but none in sparse vegetation (Table 2, Figs. 3 and 4). Only in the 2002-2003 wheatgrass 
Table 1 Melilotus frequency and mean percent cover of Melilotus, native species and other exotic species in western wheatgrass prairie and Badlands sparse vegetation from plots at random points

\begin{tabular}{|c|c|c|c|c|}
\hline & 2001 & 2002 & 2003 & 2004 \\
\hline \multicolumn{5}{|l|}{ Wheatgrass prairie } \\
\hline Melilotus frequency (\%) & $83(39 / 47)$ & $67(34 / 51)$ & $53(24 / 45)$ & NA \\
\hline Melilotus cover & $8.3 \pm 2.6$ & $3.6 \pm 0.9$ & $2.4 \pm 0.9$ & NA \\
\hline Native cover & $100.2 \pm 4.0$ & $73.7 \pm 4.0$ & $67.7 \pm 3.8$ & NA \\
\hline Exotic cover & $18.9 \pm 2.8$ & $10.7 \pm 1.5$ & $26.1 \pm 3.5$ & NA \\
\hline Bare ground cover & $1.6 \pm 0.9$ & $4.0 \pm 1.2$ & $10.3 \pm 2.1$ & NA \\
\hline Native richness & $8.5 \pm 0.7$ & $10.8 \pm 0.7$ & $14.4 \pm 0.9$ & NA \\
\hline Exotic richness & $2.8 \pm 0.2$ & $2.6 \pm 0.3$ & $4.2 \pm 0.3$ & NA \\
\hline \multicolumn{5}{|l|}{ Sparse vegetation } \\
\hline Melilotus frequency $(\%)$ & $55(24 / 44)$ & $46(23 / 50)$ & $54(22 / 41)$ & $29(14 / 49)$ \\
\hline Melilotus cover & $3.3 \pm 0.9$ & $1.7 \pm 0.5$ & $1.8 \pm 0.4$ & $1.0 \pm 0.4$ \\
\hline Native cover & $43.6 \pm 12.5$ & $24.2 \pm 3.1$ & $25.6 \pm 3.1$ & $16.6 \pm 2.4$ \\
\hline Exotic cover & $4.1 \pm 1.0$ & $3.1 \pm 0.5$ & $5.5 \pm 1.0$ & $2.1 \pm 0.4$ \\
\hline Bare ground cover & $68.3 \pm 4.1$ & $84.6 \pm 2.1$ & $84.9 \pm 2.3$ & $87.1 \pm 1.7$ \\
\hline Native richness & $5.6 \pm 0.6$ & $6.5 \pm 0.7$ & $8.2 \pm 0.8$ & $5.6 \pm 0.7$ \\
\hline Exotic richness & $1.0 \pm 0.2$ & $1.2 \pm 0.2$ & $1.7 \pm 0.2$ & $0.8 \pm 0.2$ \\
\hline
\end{tabular}

Melilotus frequency is the percent of plots with Melilotus (number of plots with Melilotus divided by total number of plots). Mean percent cover and richness $( \pm \mathrm{SE})$ for Melilotus, natives, and other exotics are presented for each year. NA = not available, data were not collected in that year

prairie model did Melilotus in one year have a positive association with exotic species in the next year, but there was no association with native species.

Q3 Is there a negative relationship between other exotic species cover and native species cover in either year $a$ or between years?

There was little evidence for a relationship between other exotic and native species cover in the wheatgrass prairie vegetation, with only one weak negative association in 2001 (Fig. 3). Significant associations were more numerous and generally positive in the sparse vegetation; we found only one negative association, between other exotic cover in 2002 and native cover in 2003 (Fig. 4).

Q4 Does the cover of Melilotus, natives, or other exotics in year a influence cover of Melilotus, natives, or other exotics, respectively, in year $a+1$ ?

Of all potential pathways, the cover of each group in year $a$ had the largest effect on the cover of the same group in year $a+1$. All associations were positive and strong (Figs. 3 and 4), with one exception: the pathway between native cover in 2001 and 2002 in wheatgrass prairie was nonsignificant (Fig. 3a).
Q5 Does the cover of native and other exotic species in year $a$ influence Melilotus cover in year $a+1 ?$

Melilotus cover was not strongly affected by the cover of native and other exotic species in the previous year. In wheatgrass prairie, there was no association between native or other exotic species cover and Melilotus cover in the second year (Fig. 3). In sparse vegetation, the association between native species cover and Melilotus cover in the second year ranged from weakly negative in 2001-2002, to weakly positive in 2002-2003 and 2003-2004 (Fig. 4). There was no association detected between the cover of other exotic species and Melilotus cover in the sparse vegetation models (Fig. 4).

Strength of associations

In general, we accounted for less of the variance in our response variables in the wheatgrass prairie model than in the sparse vegetation model; $R^{2}$ in wheatgrass prairie ranged from 0.001 to 0.36 while in sparse vegetation it ranged from 0.06 to 0.77 . Typically, the models accounted for more of the 

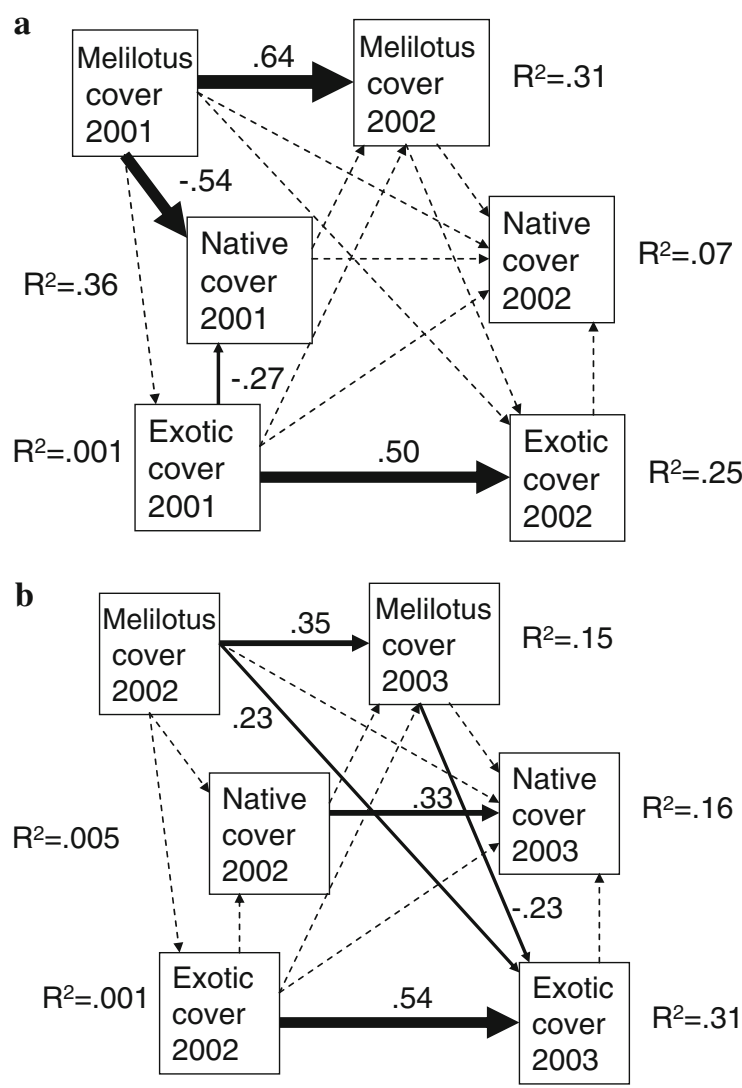

Fig. 3 Results of structural equation models of western wheatgrass prairie cover data, (a) 2001-2002; (b) 20022003. The model was consistent with the data $(N=107$ plots, $\left.\chi^{2}=1.397, \mathrm{df}=2, P=0.50\right)$. The thickness of the arrows corresponds to the magnitude of the standardized coefficients. Dashed lines with no coefficient indicate nonsignificant pathways. $R^{2}$ is reported for each dependent variable

variance in year $a+1$ than in year $a$. The only exception was in wheatgrass prairie, where the pathways from both Melilotus and other exotics resulted in a relatively high $R^{2}$ in 2001 native cover; notably, the pathway from 2001 native cover to 2002 native cover was nonsignificant and $R^{2}$ was only 0.07 for native cover in 2002 .

\section{Discussion}

Contrasting roles of Melilotus: competitor or facilitator

Our results suggest a competitive interaction between Melilotus and native species in the mesic wheatgrass
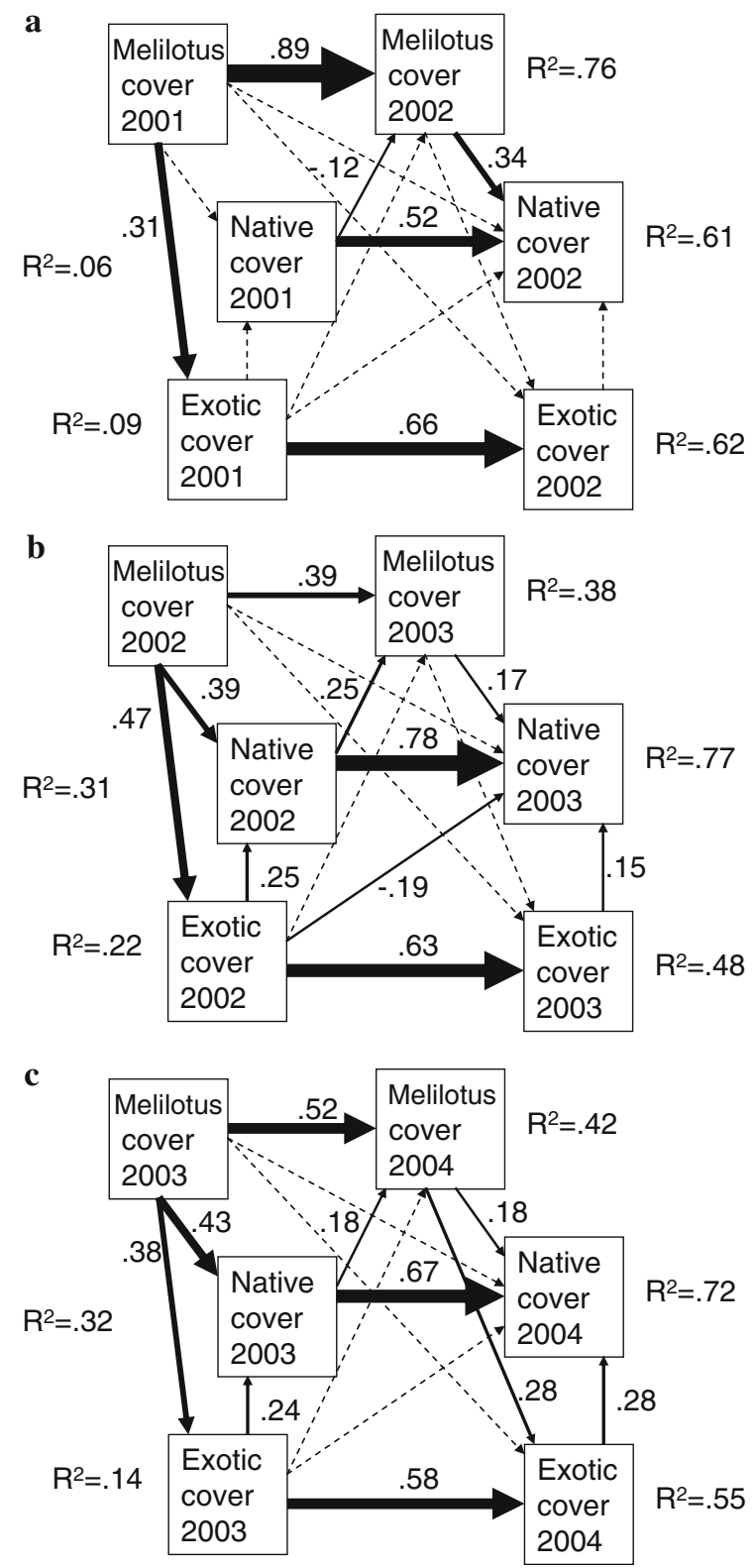

Fig. 4 Results of structural equation models of sparse vegetation cover data, (a) 2001-2002; (b) 2002-2003; (c) 2003-2004. The model was consistent with the data $(N=119$ plots, $\chi^{2}=3.845$, df $\left.=3, P=0.28\right)$. See Fig. 3 for description of notation

prairie, but a positive (perhaps facilitative) interaction in the more stressful sparse vegetation. Although we did not design our study to test the stress gradient hypothesis, in which positive interactions dominate in more stressful environments (Bertness and Callaway 1994; Brooker et al. 2008; Callaway et al. 2002), 
Table 2 Summary of significant Melilotus associations from structural equation models $(+=$ positive association with Melilotus; $-=$ negative association with Melilotus)

\begin{tabular}{|c|c|c|c|c|c|c|c|c|}
\hline \multirow[b]{3}{*}{ Model } & \multicolumn{4}{|c|}{ Same year association of Melilotus and: } & \multicolumn{4}{|c|}{ Second year association of Melilotus and: } \\
\hline & \multicolumn{2}{|c|}{ Natives } & \multicolumn{2}{|c|}{ Exotics } & \multicolumn{2}{|c|}{ Natives } & \multicolumn{2}{|c|}{ Exotics } \\
\hline & + & - & + & - & + & - & + & - \\
\hline \multicolumn{9}{|l|}{ Wheatgrass } \\
\hline 2001-2002 & & 1 & & & & & & \\
\hline 2002-2003 & & & & 1 & & & 1 & \\
\hline \multicolumn{9}{|l|}{ Sparse } \\
\hline 2001-2002 & 1 & & 1 & & & & & \\
\hline 2002-2003 & 2 & & 1 & & & & & \\
\hline 2003-2004 & 2 & & 2 & & & & & \\
\hline
\end{tabular}

For same year associations, the maximum possible number of statistically significant (at the $P<0.05$ level) effects is 2 . For example, if both the association of Melilotus in year $a$ with native cover in year $a$ and the association of Melilotus in year $a+1$ with native cover in year $a+1$ were significant, then there would be two significant effects. For second year associations, the maximum possible number of statistically significant associations is 1 (for example, the association of Melilotus cover in year $a$ with native cover in year $a+1)$

these results are consistent with its predictions. In the harsh sparse vegetation environment, we found a facilitative role for Melilotus, which had a consistent, positive relationship with cover of native and exotic species within a given year (Table 2). Melilotus has been shown to increase soil $\mathrm{N}$ in sparse vegetation soils (Van Riper 2005), and other species may benefit from this enrichment. Additionally, in dry environments, nurse plants can facilitate species growth by protecting other species from desiccation, wind, and erosion (Bruno et al. 2003; O'Connor 1995; Shumway 2000; Smith et al. 2004). Alternatively, the limited number of hospitable locations within the sparse vegetation may be responsible for the associations among Melilotus, native and other exotic vegetation, consistent with other observational studies in which relatively richer sites support more exotics as well as more natives (Chaneton et al. 2002; Lonsdale 1999; Stohlgren et al. 1999).

Lag effects

Although we expected to find a weak lag effect of Melilotus on exotic vegetation because of its $\mathrm{N}$-fixing abilities, we found virtually no effect. The only exception was a positive relationship between sweetclover cover in 2002 and other exotic cover in 2003 in the wheatgrass prairie vegetation. Nitrogen enrichment from Melilotus apparently did not create a more favorable environment for exotic species in the subsequent year, or $\mathrm{N}$ enrichment did not occur at a scale that would benefit other exotics. The lack of a lag effect may mean that native and exotic species responded similarly to increased $\mathrm{N}$ (Thomsen et al. 2006) or that Melilotus is not substantially changing the nutrient environment of the site, at least at the low densities we observed in this study. A fertilization experiment at Badlands National Park showed that $\mathrm{N}$ was not limiting in wheatgrass prairie (Van Riper 2005), so effects of $\mathrm{N}$ addition are unlikely there. In contrast, this same fertilization experiment indicated that $\mathrm{N}$ was limiting in sparse vegetation, but propagule pressure determined the effect of $\mathrm{N}$ addition on vegetation (Van Riper 2005). Because the effect was dependent on propagule pressure, which would be expected to produce a patchy expression on the landscape, our observational study would be unlikely to detect it.

\section{Effect size}

The best predictor for cover of natives, other exotics, and Melilotus in each vegetation type was that cover type in the previous year. The effect size of Melilotus and exotic species on native species was less than the effect size of the cover of native species in the previous year, although generally not less than half as strong. While sweetclover associations with natives and exotics were smaller than associations of natives and exotics with themselves, the associations with 
sweetclover are not insignificant. Many of the common species in these ecosystems are perennials (Great Plains Flora Association 1986), so continuity from year-to-year outweighs the effects of Melilotus, at least in the short term. However, studies of long-term $\mathrm{N}$ addition find shifts in the plant community, even in communities originally dominated by perennials (Carson and Barrett 1988; Samuel and Hart 1998; Wedin and Tilman 1996). Because we do not have information on plant communities at our study sites prior to Melilotus invasion, we do not know how these communities may have changed in the long term.

Generality of the model relationships

Our data were found to be consistent with our hypothesized model over the time steps examined for each vegetation type. This suggests the general utility of the modeled relationships for this system. We note that, even though some hypothesized pathways never differed significantly from 0 (e.g., Melilotus cover in yr $a$ to native cover in yr $a+1)$, we have retained them in the model because they are biologically sensible; to drop them would risk over-fitting the model to the data we collected in this relatively short study.

The strength of the modeled relationships varied from year-to-year, perhaps reflecting variability in environmental conditions, such as precipitation and temperature. The lowest $R^{2}$ values were in the wheatgrass prairie models, indicating that factors not explicit in our models, such as precipitation, likely had a large impact on the observed cover values, while this may not be the case for sparse vegetation. Seedling establishment of Melilotus has been shown to be sensitive to water availability (Tobe and Gao 2007). As a result of relatively dry years in 2002-2004 (Fig. 1), there were few plots with $>25 \%$ Melilotus cover. If wetter years result in higher Melilotus cover, stronger effects may be expected. Increased water has been shown to make $\mathrm{N}$ fixation more favorable under $\mathrm{N}$-limited conditions and to increase legume competitive ability over nonlegumes (Lauenroth and Dodd 1979). In drier years, water may be limiting to Melilotus, natives, and other exotics; when water is no longer limiting, $\mathrm{N}$ limitation may make effects of Melilotus more apparent (Lorenz and Rogler 1972; Samuel and Hart 1998; Wight and Black 1979).
Management implications

Melilotus is having an effect on vegetation at Badlands National Park, even at the relatively low cover levels we observed in this study. Because Melilotus is well-known for its episodic "boom" years, we would anticipate stronger effects during these outbreaks. Unfortunately, its widespread distribution throughout the park and outside park boundaries, as well as its economic value to beekeepers and livestock producers, makes control of Melilotus at landscape scales unlikely. Because effects were most pronounced in sparse vegetation, where presence of Melilotus generally was associated with enhanced cover of both natives and exotics, management might best focus on these other exotics, which may prove more amenable to control.

Although we found a positive association between Melilotus and native plant cover in the sparse vegetation, the accumulation of plant biomasswhether native or exotic-may result in a fundamental change to an emblematic feature of Badlands National Park. As the stark spires of the Badlands gradually become more vegetated, soil will be stabilized and erosion may slow, eventually adding enough organic matter to the soils to favor the prairie species currently surrounding them. Melilotus seems likely to speed this process.

Acknowledgments Funding was provided by a National Science Foundation Graduate Research Fellowship, a grant from the U.S. Geological Survey (USGS) Natural Resources Preservation Program, USGS Northern Prairie Wildlife Research Center, and Badlands National Park. D.A. Buhl, J.B. Grace, L.D. Igl, A. Symstad, and two anonymous reviewers provided valuable comments on previous versions of this manuscript. At Badlands National Park, S. Dingman and B. Kenner provided logistical support. Several field crews contributed to data collection. J.B. Grace provided assistance in designing and interpreting the structural equation models. Any use of trade, product, or firm names is for descriptive purposes only and does not imply endorsement by the U.S. Government.

\section{References}

Adler PB, D'Antonio CM, Tunison JT (1998) Understory succession following a dieback of Myrica faya in Hawai' 1 Volcanoes National Park. Pac Sci 52:69-78

Arbuckle JL (2006) Amos 7.0 user's guide. Amos Development Corporation, Spring House, PA, USA

Arendt JD (1997) Adaptive intrinsic growth rates: an integration across taxa. Q Rev Biol 72:149-177. doi:10.1086/419764 
Bertness MD, Callaway R (1994) Positive interactions in communities. Trends Ecol Evol 9:191-193. doi:10.1016/ 0169-5347(94)90088-4

Brooker RW, Maestre FT, Callaway RM, Lortie CL, Cavieres LA, Kunstler G et al (2008) Facilitation in plant communities: the past, the present, and the future. $\mathrm{J}$ Ecol 96:18-34

Bruno JF, Stachowicz JJ, Bertness MD (2003) Inclusion of facilitation into ecological theory. Trends Ecol Evol 18:119-125. doi:10.1016/S0169-5347(02)00045-9

Callaway R, Brooker RW, Choler P, Kikvidze Z, Lortiek CJ, Michalet $R$ et al (2002) Positive interactions among alpine plants increase with stress. Nature 417:844-848. doi: 10.1038/nature00812

Carino D, Daehler C (2002) Can inconspicuous legumes facilitate alien grass invasions? Partridge peas and fountain grass in Hawaii. Ecography 25:33-41. doi:10.1034/j. 1600-0587.2002.250105.x

Carson WP, Barrett GW (1988) Succession in old-field plant communities-effects of contrasting types of nutrient enrichment. Ecology 69:984-994. doi:10.2307/1941253

Chaneton EJ, Perelman SB, Omacini M, Leon RJC (2002) Grazing, environmental heterogeneity, and alien plant invasions in temperate Pampa grasslands. Biol Invasions 4:7-24. doi:10.1023/A:1020536728448

Clark FE, Cole CV, Bowman RA (1980) Nutrient cycling. In: Breymeyer AI, VanDyne GM (eds) Grasslands, systems analysis, and man. Cambridge University Press, Cambridge

Cousens R, Mortimer M (1995) Dynamics of weed populations. Cambridge University Press, Cambridge, UK

Daubenmire RF (1959) A canopy coverage method of vegetation analysis. Northwest Sci 33:43-64

ESRI (2001) ArcView version 8.1. Environmental Systems Research Institute (ESRI), Inc, Redlands, CA

Fogarty G, Facelli JM (1999) Growth and competition of $C y$ tisus scoparius, an invasive shrub, and Australian native shrubs. Plant Ecol 144:27-35. doi:10.1023/A:1009808 116068

Grace JB (2006) Structural equation modeling and natural systems. Cambridge University Press, Cambridge, UK

Great Plains Flora Association (1986) Flora of the Great Plains. University Press of Kansas, Lawrence, KS

Hatcher L (1994) A step by step approach to using the SAS system for factor analysis and structural equation modeling. SAS Institute, Inc, Cary, NC

Haubensak KA, Parker IM (2004) Soil changes accompanying invasion of the exotic shrub Cytisus scoparius in glacial outwash prairies of western Washington. Plant Ecol 175:7179. USA. doi:10.1023/B:VEGE.0000048088.32708.58

Hobbie SE (1992) Effects of plant species on nutrient cycling. Trends Ecol Evol 7:336-339. doi:10.1016/0169-5347(92) 90126-V

Jöreskog KG, Sörbom D (1996) LISREL 8: User's reference guide. Scientific Software International, Chicago, IL

Klebesadel LJ (2001) Extreme northern acclimatization in biennial yellow sweetclover (Melilotus officinalis) at the Arctic Circle. Univ Alsk Agric For Experiment Stn Bull 89:1-21

Lauenroth WK, Dodd JL (1979) Response of native grassland legumes to water and nitrogen treatments. J Range Manage 32:292-294. doi: $10.2307 / 3897834$
Lesica PL, DeLuca TH (2000) Melilotus: a potential problem for the northern Great Plains. J Soil Water Conserv 55:259-261

Lonsdale WM (1999) Global patterns of plant invasions and the concept of invasibility. Ecology 80:1522-1536

Lorenz RJ, Rogler GA (1972) Forage production and botanical composition of mixed prairie as influenced by nitrogen and phosphorus fertilization. Agron J 64:244-249

Mack RN, Simberloff D, Lonsdale WM, Evans H, Clout M, Bazzaz FA (2000) Biotic invasions: causes, epidemiology, global consequences, and control. Ecol Appl 10:689-710. doi:10.1890/1051-0761(2000)010[0689:BICEGC]2.0.CO;2

Maron JL, Connors PG (1996) A native nitrogen-fixing shrub facilitates weed invasion. Oecologia 105:302-312. doi: $10.1007 / \mathrm{BF} 00328732$

Maron JL, Jefferies RL (1999) Bush lupine mortality, altered resource availability, and alternative vegetation states. Ecology 80:443-454

Maron JL, Jeffries RL (2001) Restoring enriched grasslands: effects of mowing on species richness, productivity, and nitrogen retention. Ecol Appl 11:1088-1100. doi: 10.1890/1051-0761(2001)011[1088:REGEOM]2.0.CO;2

McCune B, Grace JB (2002) Analysis of ecological communities. MjM Software Design, Gleneden Beach, OR

McLendon T, Redente EF (1992) Effects of nitrogen limitation on species replacement dynamics during early secondary succession on a semiarid sagebrush site. Oecologia 91:312-317. doi:10.1007/BF00317618

Mitchell RJ (1993) Path analysis: pollination. In: Scheiner SM, Gurevitch J (eds) Design and analysis of ecological experiments. Chapman and Hall, New York, NY

Mooney HA, Drake JA (1986) Ecology of biological invasions of North America and Hawai'i. Springer-Verlag, New York

Nielsen RD (1996) Soil survey of Custer and Pennington counties, prairie parts, South Dakota. Natural Resources Conservation Service. U.S. Department of Agriculture, Huron, SD

O'Connor TG (1995) Acacia karroo invasion of grassland: environmental and biotic effects influencing seedling emergence and establishment. Oecologia 103:214-223. doi:10.1007/BF00329083

Rejmanek M, Richardson DM (1996) What attributes make some plant species more invasive? Ecology 77:16551661. doi: $10.2307 / 2265768$

Samuel MJ, Hart RH (1998) Nitrogen fertilization, botanical composition and biomass production on mixed-grass rangeland. J Range Manage 51:408-416. doi:10.2307/ 4003325

Schlepp RL (1987) Soil survey of Jackson county, northern part, South Dakota. Natural Resources Conservation Service, U.S. Department of Agriculture, Huron, SD

Sher A, Hyatt L (1999) The disturbed resource-flux invasion matrix: a new framework for patterns of plant invasion. Biol Invasion 1:107-114. doi:10.1023/A:1010050420466

Shumway SW (2000) Facilitative effects of a sand dune shrub on species growing beneath the shrub canopy. Oecologia 124:138-148. doi:10.1007/s004420050033

Simberloff D (2006) Invasional meltdown 6 years later: important phenomenon, unfortunate metaphor, or both? Ecol Lett 9:912-919. doi:10.1111/j.1461-0248.2006. 00939.x 
Simberloff D, Von Holle B (1999) Positive interactions of nonindigenous species: invasional meltdown? Biol Invasions 1:21-32. doi:10.1023/A:1010086329619

Smith MD, Wilcox JC, Kelly T, Knapp AK (2004) Dominance not richness determines invasibility of tallgrass prairies. Oikos 106:253-262. doi:10.1111/j.0030-1299.2004.13057.x

Stohlgren TJ, Binkley D, Chong GW, Kalkhan MA, Schell LD, Bull KA et al (1999) Exotic plant species invade hot spots of native plant diversity. Ecol Monogr 69:25-46

Thomsen MA, Corbin JD, D'Antonio CM (2006) The effect of soil nitrogen on competition between native and exotic perennial grasses from northern coastal California. Plant Ecol 186:23-35. doi:10.1007/s11258-006-9109-4

Tilman D (1987) Secondary succession and the pattern of plant dominance along experimental nitrogen gradients. Ecol Monogr 57:189-214. doi:10.2307/2937080

Tobe K, Gao Y (2007) Seed germination and seedling emergence of herbs in sand. Aust J Bot 55:55-62. doi: 10.1071/BT06060

Turkington RA, Cavers PB, Empel E (1978) The biology of Canadian weeds. 29. Melilotus alba Desr. and M. officinalis (L.) Lam. Can J Plant Sci 58:523-537

Van Riper LC 2005. The role of the exotic legume yellow sweetclover (Melilotus officinalis) in a low nitrogen system: a potential ecosystem transformer and facilitator of invasion. Ph.D. dissertation. Department of Ecology, Evolution and Behavior, University of Minnesota, St. Paul, MN

Vitousek PM, Walker LR (1989) Biological invasion by Myrica faya in Hawai'i: plant demography, nitrogen fixation, ecosystem effects. Ecol Monogr 59:247-265. doi: 10.2307/1942601

Vitousek PM, Walker LR, Whiteaker LD, Mueller-Dombois D, Matson PA (1987) Biological invasion by Myrica faya alters ecosystem development in Hawai'i. Science 238:802-804. doi:10.1126/science.238.4828.802

Von Loh J, Cogan D, Faber-Langendoen D, Crawford D, Pucherelli MJ (1999) USGS-NPS vegetation mapping program, Badlands National Park, South Dakota. US Department of Interior, Bureau of Reclamation, Denver, $\mathrm{CO}$
Walker LR, Vitousek PM (1991) An invader alters germination and growth of a native dominant tree in Hawaii. Ecology 72:1449-1455. doi:10.2307/1941117

Weaver T, Gustafson D, Lichthardt J (2001) Exotic plants in early and late seral vegetation of fifteen northern Rocky Mountain environments (HTs). West N Am Nat 61:417-427

Wedin DA, Tilman D (1996) Influence of nitrogen loading and species composition on the carbon balance of grasslands. Science 274:1720-1723. doi:10.1126/science.274.5293.1720

Wheeler CT, Helgerson OT, Perry DA, Gordon JC (1987) Nitrogen fixation and biomass accumulation in plant communities dominated by Cytisus scoparius L. in Oregon and Scotland. J Appl Ecol 24:231-237. doi: $10.2307 / 2403800$

Wight JR, Black AL (1979) Range fertilization: plant response and water use. J Range Manage 32:345-349. doi:10.2307/ 3898012

Wilcove DS, Rothstein D, Dubow J, Phillips A, Losos E (1998) Quantifying threats to imperiled species in the United States. Bioscience 48:607-615. doi:10.2307/1313420

Willems JH, Peet RK, Bik L (1993) Changes in chalk-grassland structure and species richness resulting from selective nutrient additions. J Veg Sci 4:203-212. doi:10.2307/ 3236106

Wivstad M (1999) Nitrogen mineralization and crop uptake of $\mathrm{N}$ from decomposing $\mathrm{N}-15$ labelled red clover and yellow sweetclover plant fractions of different age. Plant Soil 208:21-31. doi:10.1023/A:1004407119638

Wolf JJ, Beatty SW, Carey G (2003) Invasion by sweet clover (Melilotus) in montane grasslands, Rocky Mountain National Park. Ann Assoc Am Geogr 93:531-543. doi: 10.1111/1467-8306.9303001

Woodmansee RG (1978) Additions and losses of nitrogen in grassland ecosystems. Bioscience 28:448-453. doi:10.2307/ 1307227

Wu S-H, Chaw S-M, Rejmánek M (2003) Naturalized Fabaceae (Leguminosae) species in Taiwan: the first approximation. Bot Bull Acad Sin 44:59-66

Zakhia F, de Lajudie P (2001) Taxonomy of rhizobia. Agronomie 21:569-576. doi:10.1051/agro:2001146 